IZA DP No. 8102

Candidates' Quality and Electoral Participation:

Evidence from Italian Municipal Elections

Marco Alberto De Benedetto

Maria De Paola

April 2014 


\title{
Candidates' Quality and Electoral Participation: Evidence from Italian Municipal Elections
}

\author{
Marco Alberto De Benedetto \\ Birkbeck College \\ Maria De Paola \\ University of Calabria \\ and IZA
}

Discussion Paper No. 8102

April 2014

IZA

P.O. Box 7240

53072 Bonn

Germany

Phone: +49-228-3894-0

Fax: +49-228-3894-180

E-mail: iza@iza.org

\begin{abstract}
Any opinions expressed here are those of the author(s) and not those of IZA. Research published in this series may include views on policy, but the institute itself takes no institutional policy positions. The IZA research network is committed to the IZA Guiding Principles of Research Integrity.

The Institute for the Study of Labor (IZA) in Bonn is a local and virtual international research center and a place of communication between science, politics and business. IZA is an independent nonprofit organization supported by Deutsche Post Foundation. The center is associated with the University of Bonn and offers a stimulating research environment through its international network, workshops and conferences, data service, project support, research visits and doctoral program. IZA engages in (i) original and internationally competitive research in all fields of labor economics, (ii) development of policy concepts, and (iii) dissemination of research results and concepts to the interested public.
\end{abstract}

IZA Discussion Papers often represent preliminary work and are circulated to encourage discussion. Citation of such a paper should account for its provisional character. A revised version may be available directly from the author. 


\section{ABSTRACT}

\section{Candidates' Quality and Electoral Participation: Evidence from Italian Municipal Elections}

We analyze the impact of the quality of candidates running for a mayor position on turnout using a large data set on Italian municipal elections held from 1993 to 2011. We firstly estimate a municipal fixed effects model and show that an increase in the average quality of candidates competing at the electoral race produces a positive impact on turnout. To handle endogeneity issues arising from time variant unobservable features of electoral races, we build on the literature showing that politicians' quality is positively affected by their wage and apply a Fuzzy Regression Discontinuity Design relying on the fact that in Italy the wage of the mayor increases non-monotonically at different thresholds. Results show that an exogenous increase in the average quality of candidates, induced by a higher wage, leads to an increase in turnout by about 2 percentage points.

JEL Classification: D72, D78, J45

Keywords: politicians' quality, turnout, fuzzy regression discontinuity design, instrumental variables

Corresponding author:

Maria De Paola

Dipartimento di Economia

Statistica e Finanza

Università degli Studi della Calabria

87030, Arcavacata di Rende

Italy

E-mail:m.depaola@unical.it

\footnotetext{
* We are grateful for invaluable help with data collection to Stefano Trulli and Nicola D'Amelio from the Italian Ministry of Internal Affair. We would like to thank Stefano Gagliarducci, Francesca Gioia, Giuseppe Rose, Vincenzo Scoppa and seminar participants at University of Calabria, for useful suggestions and comments.
} 


\section{Introduction}

Although universal suffrage is a common feature of modern societies, turnout varies considerably across countries and individuals. A large literature has investigated the main determinants of electoral participation (for a survey see, for example, Schlozman, 2002 and Matsusaka and Palda, 1999) pointing at the role played by both institutional features (electoral competition, legislature size, electoral system, etc.) and demographic characteristics (age, income, education, employment status, etc.).

Among demographic characteristics, education has received particular attention and some recent papers identify a causal effect of voters' educational attainment on turnout. Dee (2004) and Milligan et al. (2004), by exploiting changes in compulsory school laws across different regions at different times in the US, show that educational attainment in the population is related to several measures of political interest and involvement. No effects, instead, are found by Siedler (2007) for Germany and by Borgonovi et al. (2010) for a number of European countries.

Education, rising individual ability to understand the issues at stake and to monitor elected politicians, also increases the ability to select more able politicians and to improve the working of the political system. For example, Glaeser et al. (2007) argue that democracies are more stable when citizens are more educated. Accetturo (2013), using Italian data, shows that cities with a higher endowment of human capital tend to select mayors with ex-ante better characteristics.

In this paper we take a different point of view and instead of considering the effect produced by the educational level of electors on turnout, we focus on the effect produced by the educational level of candidates at elections. Education is often considered as a proxy for politicians' quality and having high skilled candidates at the electoral race may induce individuals to cast their vote because they may infer a higher political competence.

Even if the economic and political literature has investigated the impact of the quality of politicians on a quite large number of outcomes, little is known on its impact on electoral turnout. Even so, political participation is at the basis of a well-functioning political system. A greater political participation is of extreme importance to strengthen the legitimacy of democratic institutions: it changes political outcomes, since subjects who vote affect the type of policies implemented by the government, and it is likely to improve social outcomes as it reveals and aggregates preferences (Pateman, 1970; Barber, 1984).

As far as we know, this is the first paper trying to disentangle the impact of politicians' quality on political participation. ${ }^{1}$ At this aim we use a rich data set providing information both on turnout at Italian municipal elections (for the period 1993-2011) and on the characteristics of candidates competing at these elections. To handle endogeneity problems that derive from unobservable factors that might affect both turnout and the quality of individuals deciding to enter the electoral race, we firstly estimate a municipal fixed effects model. This model allows us to neutralize possible bias due to unobservable time invariant municipal

\footnotetext{
${ }^{1}$ A number of papers focusing on US elections show that the strategic decision to stand as a challenger in an electoral contest is influenced by the quality of the incumbent and that high quality candidates have more electoral success (see Jacobson and Kernell, 1983; Lublin, 1994; Carson et al., 2001; Stone et al., 2003 and Stone et al., 2010).
} 
characteristics that might affect both candidates' quality and electors' decision to show up at the polls. These estimates highlight that an increase in the average level of education of candidates at the electoral race produces an increase in turnout.

Since endogeneity problems might also be related to some unobservable features of each electoral race (time variant), we also apply a Fuzzy Regression Discontinuity Design relying on the fact that in Italy the wage of the mayor increases at different population thresholds. As already shown by Gagliarducci and Nannicini (2011) and by Ferraz and Finan (2009), the wage paid to elected officials has a positive impact on candidates' quality. Gagliarducci and Nannicini (2011), using the same data we adopt in this paper (but for a smaller sample and for a shorter time period) also show that the wage does not affect other candidates' characteristics (such as age and gender) and that its impact on politicians' performance is mainly due to the effect produced on politicians' quality. Their results reassure us about the fact that the exogenous variation in wage should not affect turnout through other channels rather than the quality of candidates at the electoral race. Our fixed effects estimates go in the same direction, showing that the positive effect of politicians' quality on turnout is not due to unobserved time invariant municipal characteristics (for instance, higher campaign expenditures that might be related to the payment of a higher wage. The real wage does not change much over time and only few municipalities experiment changes in the population size implying in turn a change in the thresholds that define the wage paid to the Mayor and to the members of the Executive Committee).

We focus on 3 (out of 9) population thresholds (1,000; 5,000 and 50,000 inhabitants) that uniquely identify a wage increase and apply a Fuzzy Regression Discontinuity Design. Our First Stage regression results confirm that the wage strongly affects the average educational level of candidates competing for election. Second Stage regression results highlight that an exogenous increase in the average quality of politicians produces a positive impact on turnout. An increase of 1 year in the average years of education of candidates at the electoral race produces an increase in turnout of about 2 percentage points. We also find, by exploiting data on turnout available separately by gender, that female and male electors react similarly to candidates' quality.

Results are robust to different functional forms of the population size and when, instead of using the wage, we use the three population cutoffs that uniquely identify an increase in the mayor's wage as excluded instruments. We also control for candidates' average age, for the proportion of female candidates, for the presence of the incumbent mayor among candidates and for the degree of electoral competition.

Our analysis is related to the literature investigating the relationship between politicians' quality (typically measured considering education) and a number of performance indicators, such as growth, type of policies implemented and efficiency of the public administration. ${ }^{2}$ Jones and Olken (2005) and Besley et al. (2011) look at the relationship between politicians' quality and growth and find that growth is higher when

\footnotetext{
${ }^{2}$ Besley and Coate (1997) and Osborne and Slivinski (1996) provide a theoretical framework showing the relevance of politicians' quality for policy choices.
} 
leaders are more educated. ${ }^{3}$ Gagliarducci and Nannicini (2011) and Ferraz and Finan (2009), investigating the effects of remuneration on the quality and productivity of politicians, show that more educated politicians perform better. We add to this literature showing that the quality of politicians also affects political participation, probably because electors expect a better performance.

Our work is also related to the theoretical literature examining the individual decision to enter politics (Caselli and Morelli, 2004; Messner and Polborn, 2004; Poutvaara and Takalo, 2007). In these models, on the one hand, a high-skilled individual has a higher outside option and consequently a higher opportunity cost of entering politics, but on the other hand he/she also has a higher probability of winning an election, as voters would like to have competent office holders. However, the empirical analysis testing these theoretical assumptions is scant. Little is known on whether candidates with higher ability obtain a larger share of votes and on whether high-quality politicians increase electoral participation by inducing some unconvinced voters to cast their vote. ${ }^{4}$

The paper is organized in the following way. Section 2 is devoted to the description of the institutional framework and of our data set. In Section 3, we present municipal fixed effects estimates. In Section 4 we present results obtained when using a Fuzzy Regression Discontinuity design. In section 5 we report some robustness checks. Section 6 concludes.

\section{Institutional framework and data}

The system currently regulating municipal elections in Italy has been introduced in 1993 (Law no. 81 of March 25, 1993). It has established the direct election of the mayor and the adoption of the plurality rule, with some differences according to the size of the resident population. ${ }^{5}$ The Municipal Council (Consiglio Comunale) is endowed with legislative powers, while the executive authority is assigned to a Mayor (Sindaco) who heads an Executive Committee (Giunta Comunale).

Municipalities have a registry of eligible voters, which is revised whenever there is an election and all citizens aged 18 or more on the election date are automatically registered to vote. Elections usually last two consecutive days (Sunday and Monday). Voting takes place in polling stations organized by the local authorities. Elections are organized according to a traditional paper ballot system.

To recover the effect of candidates' quality on turnout we both rely on municipal fixed effects estimates and on the exogenous variation in the remuneration obtained by local administrators. In Italy, the remuneration

\footnotetext{
${ }^{3}$ See also Besley et al. (2007), Jones and Olken (2005) and Besley (2007).

${ }^{4}$ A number of works have analyzed which factors affect the selection of more educated politicians, looking at the impact produced by political competition (De Paola and Scoppa, 2011; Galasso and Nannicini, 2011), resources (Brollo et al., 2012), citizens’ education (Accetturo, 2013) and gender quotas (Baltrunaite et al., 2012).

${ }^{5}$ For municipalities with a population of less than 15,000 inhabitants, elections are held with single ballot and plurality rule, and the winning candidate is awarded a majority premium of at least two-thirds of the seats in the Council; for municipalities with a population above 15,000, elections are held with a dual ballot (where the second is held if none of the candidates in the first ballot obtained an absolute majority of the votes), and the winning candidate is awarded a majority premium of at least 60 percent of the seats on the Council.
} 
obtained by the Mayor and the Executive Committee members depends on the size of the resident population, as measured by the National Census every ten years. ${ }^{6}$ Remuneration changes at nine different thresholds. However, a number of other policies are determined by population cutoffs. ${ }^{7}$ While some of these polices, such as the change in the wage is likely to affect the quality of candidates at the electoral race, but should not be related to voter turnout through other channels, other policies, defining the size of the municipal council may directly affect electoral participation. Then, we focus on the 3 (out of the 9) thresholds that uniquely identify a wage increase: 1,000, 5,000 and 50,000 inhabitants. ${ }^{8}$ To give an idea of the increase in the major's wage, consider that at the 1,000 threshold there is an increase of about 13\%, while at the 5,000 and 50,000 thresholds the mayor's gross wage raises by $30 \%$ and $20 \%$ respectively.

We restrict the analysis to the 1,000,5,000 and 50,000 thresholds, and to stay sufficiently away from other policy thresholds we consider the sample of cities respectively between 800 and 1,200 inhabitants, between 3,000 and 6,000 inhabitants, and between 40,000 and 60,000. We end up with 4,578 observations: 1,614 below and above the 1,000 threshold, 2,666 below and above the 5,000 threshold and 298 above and below the 50,000 threshold. Our sample contains about 22.35 percent of all Italian municipalities.

Data on electoral participation are provided by the Italian Ministry of Internal Affairs. From this source we collected a panel data set on municipal elections held over the period 1993-2011. We have information on the number of valid, invalid and blank ballots, the number of people eligible to vote, the number of candidates and the votes they received. ${ }^{9}$ On the basis of this information we build our dependent variable Turnout as the ratio between the number of total ballots and the number of people eligible to vote (i.e. number of voters on the number of electors).

We also observe for most of the municipalities the number of electors and voters separately for males and females. In this way we are able to distinguish between Male Turnout, the ratio between male voters and male electors, and Female Turnout, the ratio between female voters and female electors. Unfortunately, for a number of elections (in particular for the years 1996-1999) there was no separate account of electors and voters between males and females and as a consequence our sample is reduced.

As shown in Table 1 in which we report the main descriptive statistics for our sample, the average turnout is about $79 \%$. Electoral participation is similar for males and females, $81.3 \%$ and $79.9 \%$ respectively, during the period covered by our data.

\footnotetext{
${ }^{6}$ For a detailed description of the system see Gagliarducci and Nannicini (2011).

${ }^{7}$ Since the magnitude of the compensation of the executive committee is small, we can suppose that the effect of increasing the remuneration of elected officials is driven by the mayor's wage. Even if the wage is not the only source of income for mayors, as discussed by Gagliarducci and Nannicini (2011) the fraction of mayors earning extra income is similar for towns above and below the cutoffs defining the mayor's wage. In addition, although under specific and documented circumstances, the executive committee can grant up to an additional 15\% increase to the mayor's remuneration, conditional on the approval of the Ministry of Internal Affairs, according to a survey conducted by Gagliarducci and Nannicini (2011) only very few municipalities introduced a wage raise.

${ }^{8}$ Since the wage increase at 1,000 was only introduced in April 2000 we have excluded from our analysis electoral results concerning these municipalities for the period 1993-1999.

${ }^{9}$ The data on electoral turnout were kindly provided by the Italian Ministry of Internal Affairs. Only starting from 2001, data on electoral outcomes are available at the following website: http://elezionistorico.interno.it/ (Archivio Storico delle Elezioni).
} 
To measure candidates' quality we use a data set on local administrators (Italian Ministry of Internal Affairs), providing information on the identity, gender, age and the highest educational attainment of candidates running for the mayor position. Since it is not possible to find one or more indicators that unquestionably determine what makes a good politician, we measure politicians' quality in terms of human capital. There is a huge economic literature showing that a higher accumulation of human capital produces positive effects both on individual economic prospects and on aggregate variables. Under the assumption that “political” and "market” skills are correlated, human capital should also represent a good proxy for politicians' quality (De Paola and Scoppa, 2011, and Baltrunaite et al., 2012, use similar measures of politicians' quality).

Using information on the educational attainment of candidates running for the mayor position at each electoral race, we build two variables Candidates' Education and Candidates' Max Education, which measure respectively the average number of years of schooling of candidates and the educational level of the candidate who has acquired the highest level of education compared to the whole pool of candidates. The average number of years of schooling of candidates running for a mayor position (Candidates' Education) is about 14.44. ${ }^{10}$ Candidates' education increases with the population size. In small cities with a number of inhabitants between 800 and 1,200, candidates' years of education are 13.69, while in larger cities education is higher (on average 14.71 for cities with 4,000-6,000 inhabitants and 15.89 for cities below and above the 50,000 threshold). Moreover, the maximum educational level among candidates, Candidates' Max Education, is on average 16.46.

As far as other candidates' characteristics are concerned, in our sample candidates have an average age of 48. Less than $26 \%$ of competitions featured a female among the competing candidates. In $39 \%$ of electoral races there is, among candidates running for the mayor position, a candidate (Incumbent) that has already performed this charge in the previous legislature.

Using data on the number of candidates at each electoral race and on the votes they received we are able to build two measures describing the degree of political competition characterizing the electoral race. The first measure is simply given by the number of candidates, while the second one (Electoral Margin) is the difference between the number of votes obtained by the two leading candidates divided by the number of eligible voters.

\footnotetext{
${ }^{10}$ As the information on candidates' education is not always reported, we have restricted our sample to those cases in which we observe at least the educational level of two candidates. In the selected sample, for $75 \%$ of the observations we have information on the educational level of all candidates competing at the electoral race, for about $20 \%$ of observations we miss information on the educational level of one candidate and for the remaining $5 \%$ of observations there is more than one candidate for which we do not observe the educational level.
} 
Table 1. Descriptive Statistics

\begin{tabular}{lccccc}
\hline Variables & Mean & Std. Dev. & Min & Max & Observations $^{\mathbf{1 1}}$ \\
\hline Turnout & 0.793 & 0.086 & 0.139 & 0.984 & 4,578 \\
Female Turnout & 0.799 & 0.083 & 0.123 & 0.979 & 2,579 \\
Male Turnout & 0.813 & 0.092 & 0.157 & 0.969 & 2,598 \\
Candidates' Education & 14.440 & 2.415 & 5 & 18 & 4,578 \\
Candidates' Max Education & 16.456 & 2.462 & 5 & 20 & 4,578 \\
Percentage of High Skill Candidates & 0.418 & 0.325 & 0 & 1 & 4,578 \\
Candidates' Age & 48.164 & 6.990 & 24 & 72 & 4,578 \\
Female Candidate & 0.256 & 0.437 & 0 & 1 & 4,578 \\
Incumbent & 0.387 & 0.487 & 0 & 1 & 4,578 \\
No. Candidates & 2.937 & 1.182 & 2 & 12 & 4,578 \\
Electoral Margin & 0.191 & 0.161 & 0 & 0.954 & 4,578 \\
Municipal Area (Square Km) & 37.421 & 49.877 & 0 & 594 & 4,578 \\
Population Size/1,000 & 6.411 & 11.533 & 0.801 & 59.907 & 4,578 \\
Population Education & 7.057 & 0.861 & 4.505 & 10.029 & 4,578 \\
Employment & 0.257 & 0.136 & 0.047 & 0.839 & 4,578 \\
Mayor's Wage & $2,061.41$ & 679.18 & 1,190 & 4,466 & 4,578 \\
\hline \hline
\end{tabular}

Notes: Data from the Italian Ministry of Internal Affairs and from the 1991 and 2001 Italian Census (ISTAT).

We also have information on some time-invariant municipal characteristics, such as the municipal area size, that is about 37.42 square kilometers. Finally, we use the 1991 and 2001 Italian Census of Population to obtain time varying information at municipal level regarding population size, the number of employed individuals and the educational attainment of the population. ${ }^{12}$ The average population size of Italian municipalities is 6,411. The population's number of years of education is, on average, 7.06 and the ratio between the number of employed individuals and the total number of inhabitants is $25.7 \%$.

In our sample the wage paid to Mayors is on average 2,061 Euros with a minimum value of 1,190 Euros and a maximum value of about 4,466 Euros.

\section{Municipal fixed effects estimates}

Italy is characterized by a quite high electoral turnout compared to many European countries and to US. Turnout is high also in local elections. Municipal administrations in Italy are responsible for a number of relevant functions, such as the management of public utilities and the provision of some services, having a strong impact on the daily life of citizens. As a consequence, voters are generally strongly interested in the choice of the mayor and in the composition of the Municipal Council. In our sample for the period 1993-2011, the average turnout in municipal elections has been 79.3\%. However, from 1993 to 2011 the average electoral participation has decreased from $82 \%$ to $74.4 \%$ suggesting that also in Italy voter turnout may become a concern.

\footnotetext{
${ }^{11}$ The number of observations refers to the regression in which we add all our control variables with a bandwidth of 20 percent below and above the three thresholds.

${ }^{12}$ We use the 1991 census for elections taking place from 1993 to 1997 and the 2001 census for elections taking place since 1998.
} 
In this section, at the aim of understanding whether turnout is affected by the quality of politicians, we exploit the panel nature of our data set and estimate the following model by OLS with fixed effects at municipal level:

\section{[1] Turnout $_{i t}=\beta_{0}+\beta_{1}$ Candidates' $^{\prime}$ Quality $_{i t}+\beta_{3} X_{i t}+\varphi_{i}+\mu_{t}+\varepsilon_{i t}$,}

where Turnout $_{i t}$ is the electoral participation in municipality $i$ at elections held at time $t$, as measured by the number of total ballots on the number of people eligible to vote; Candidates' Quality $_{i t}$ is our main variable of interest measuring the quality of candidates at the electoral race as the average number of years of education of candidates running for the mayor position in municipality $i$ at time $t ; X_{i t}$ is a vector including controls for municipal characteristics at the time of elections (population size, the municipality area in square kilometers, the average number of years of education of the inhabitants, the fraction of employed people in the population), candidates' characteristics (the average age of candidates, a dummy variable

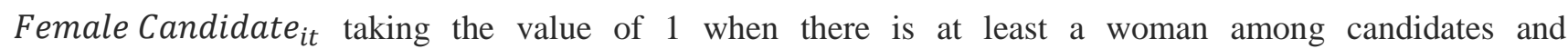
Incumbent $_{i t}$ that takes a value equal to 1 if the mayor in the previous legislature is among candidates and zero otherwise) and competition's characteristics (i.e. the degree of electoral competition as measured by the difference in votes (\%) between the winner and his/her closest challenger and the number of candidates at the electoral race). $\varphi_{\mathrm{i}}$ and $\mu_{\mathrm{t}}$ are respectively a municipal and an electoral period fixed effect. The municipal fixed effects $\varphi_{i}$ accounts for time-invariant municipal characteristics, whereas $\mu_{t}$ is used to take into account any differences across time.

Controlling for municipal fixed effects should eliminate any bias deriving from unobserved time invariant municipal characteristics that might affect both turnout and candidates' quality (for instance, time municipal characteristics that attract politicians who are better educated and also induce citizens to show up at the polls).

In Table 2, we present the within-groups estimates of electoral turnout. These estimates are based on how changes in turnout are related to changes in candidates' quality. We only present results for the sample of cities between 800 and 1,200 inhabitants, between 4,000 and 6,000 inhabitants, and between 40,000 and 60,000 for which we are also able to apply a Fuzzy Regression Discontinuity approach. However, results remain substantially unchanged when we extend our analysis to the whole sample of Italian municipalities (not reported and available upon request). 
Table 2. The Impact of Candidates’ Quality on Turnout: FE Estimates ( $\pm 20 \%$ Bandwidth). Dependent Variable Turnout

\begin{tabular}{|c|c|c|c|c|}
\hline & $(1)$ & $(2)$ & (3) & (4) \\
\hline Candidates' Education & $\begin{array}{c}0.0009 * * \\
(0.0003)\end{array}$ & $\begin{array}{c}0.0007 * * \\
(0.0003)\end{array}$ & $\begin{array}{c}0.0009 * * * \\
(0.0003)\end{array}$ & $\begin{array}{c}0.0007^{* *} \\
(0.0003)\end{array}$ \\
\hline Population Size/1,000 & $\begin{array}{c}-0.0250 * * * \\
(0.0050)\end{array}$ & $\begin{array}{c}-0.0173 * * * \\
(0.0053)\end{array}$ & $\begin{array}{c}-0.0173 * * * \\
(0.0052)\end{array}$ & $\begin{array}{c}-0.0169 * * * \\
(0.0051)\end{array}$ \\
\hline Population Size^2 & $\begin{array}{c}0.0002^{* * *} \\
(0.0000)\end{array}$ & $\begin{array}{c}0.0002^{* * *} \\
(0.0000)\end{array}$ & $\begin{array}{c}0.0002^{* * *} \\
(0.0000)\end{array}$ & $\begin{array}{c}0.0002 * * * \\
(0.0000)\end{array}$ \\
\hline Population Education & & $\begin{array}{c}0.0501 * * * \\
(0.0152)\end{array}$ & $\begin{array}{c}0.0492 * * * \\
(0.0152)\end{array}$ & $\begin{array}{c}0.0499 * * * \\
(0.0150)\end{array}$ \\
\hline Population Education^2 & & $\begin{array}{c}-0.0042 * * * \\
(0.0011)\end{array}$ & $\begin{array}{c}-0.0042 * * * \\
(0.0011)\end{array}$ & $\begin{array}{c}-0.0042^{* * *} \\
(0.0011)\end{array}$ \\
\hline Employment & & $\begin{array}{l}-0.0281 \\
(0.0292)\end{array}$ & $\begin{array}{l}-0.0296 \\
(0.0291)\end{array}$ & $\begin{array}{l}-0.0260 \\
(0.0278)\end{array}$ \\
\hline Municipal Area & & $\begin{array}{c}0.0022 \\
(0.0051)\end{array}$ & $\begin{array}{c}0.0018 \\
(0.0051)\end{array}$ & $\begin{array}{c}0.0019 \\
(0.0049)\end{array}$ \\
\hline Candidates’ Age & & & $\begin{array}{c}0.0002 \\
(0.0001)\end{array}$ & $\begin{array}{c}0.0002 \\
(0.0001)\end{array}$ \\
\hline Incumbent & & & $\begin{array}{l}-0.0009 \\
(0.0013)\end{array}$ & $\begin{array}{c}0.0003 \\
(0.0013)\end{array}$ \\
\hline Female Candidate & & & $\begin{array}{l}-0.0027 \\
(0.0022)\end{array}$ & $\begin{array}{l}-0.0018 \\
(0.0019)\end{array}$ \\
\hline No. Candidates & & & & $\begin{array}{c}0.0001 \\
(0.0006)\end{array}$ \\
\hline Electoral Margin & & & & $\begin{array}{c}-0.0288^{* * *} \\
(0.0045)\end{array}$ \\
\hline Constant & $\begin{array}{c}0.936 * * * \\
(0.0236)\end{array}$ & $\begin{array}{c}0.682^{* * *} \\
(0.203)\end{array}$ & $\begin{array}{c}0.686 * * * \\
(0.205)\end{array}$ & $\begin{array}{c}0.688 * * * \\
(0.194)\end{array}$ \\
\hline Observations & 4,601 & 4,601 & 4,601 & 4,578 \\
\hline R-squared & 0.405 & 0.413 & 0.414 & 0.469 \\
\hline Number of Municipalities & 1,766 & 1,766 & 1,766 & 1,765 \\
\hline
\end{tabular}

Notes: The dependent variable is the electoral turnout (number of total ballots on the number of electors). In all the regressions we control for electoral period dummies (not reported). Standard errors (corrected for heteroskedasticity and clusterized at the municipality level) are reported in parentheses. The symbols $* * *, * *, *$ indicate that coefficients are statistically significant, respectively, at the 1,5 , and 10 percent level.

In column (1) of Table 2, in which we only control for a linear and quadratic polynomial of population size, we find that an increase in the average quality of candidates at the electoral race produces an increase in turnout. The estimated impact is, however, small: an increase of one year in the average quality of candidates increases turnout by about 0.9 percentage points.

The same results hold true also when we add controls for municipalities' characteristics (column 2), for candidates' characteristics (column 3) and for the degree of competition characterizing the electoral race (column 4).

As far as our control variables are concerned, we find that voter turnout increases, at a decreasing rate, with the educational attainment of the population while it decreases, at a decreasing rate, with population size. Changes in the employment rate and in the size of the municipal area do not produce any statistically significant effect. Apart from education, the other candidates' characteristics for which we have information 
do not seem to be particularly relevant in shaping turnout. A strong and statistically significant effect is instead associated to Electoral Margin implying that turnout increases with the closeness of the electoral race. ${ }^{13}$

All in all our estimates highlight that having more educated candidates running for the mayor position positively affects turnout, suggesting in turn, that electors decide to go to the polls and to cast their vote when candidates are considered qualified on the basis of their educational attainment. Although municipal fixed effects estimates take into account time invariant municipal unobserved characteristics that covary with both turnout and politicians' quality, we cannot exclude that our findings are driven by time variant unobserved features. For instances, our estimates might be downward (upward) biased if there are some unobserved features of electoral races that attract high-quality candidates but discourage (encourage) citizens to go to the polls. It could also be that the decision of high-quality candidates to run for election is related to the expected turnout, for example, because it might affect the expected probability of winning the election. In the next section, we present results obtained following a different identification strategy relying on the change in candidates' quality induced by an exogenous change in their wage.

\section{Fuzzy regression discontinuity estimates}

In this section to recover the causal effect of candidates' quality on turnout we use a Fuzzy Regression Discontinuity Design exploiting the fact that the decision to enter politics is also affected by the wage earned by mayors, which in turn is a discontinuous function of the municipality population at different cutoffs. Even if population is correlated to candidates' quality, the relationship is smooth with no jump in the proximity of the cutoffs.

We estimate the following model, in which the quality of candidates is a discontinuous function of the municipality population (Lee and Lemieux, 2009; Angrist and Pischke, 2009):

$$
\begin{aligned}
& \text { Turnout }_{i t}=\beta_{0}+\beta_{1} \text { Candidates }^{\prime} \text { Quality }_{i t}+\beta_{2} f\left(\text { Pop }_{i t}\right)+\beta_{3} X_{i t}+\varphi_{i}+\mu_{t}+\varepsilon_{i t} \\
& \text { Candidates' Quality }_{i t}=\gamma_{0}+\gamma_{1} \text { Wage }_{i}+\gamma_{2} f\left(\text { Pop }_{i t}\right)+\gamma_{3} X_{i t}+\varphi_{i}+\mu_{t}+v_{i t}
\end{aligned}
$$

In equation [1] Turnout $_{i t}$ is modeled in relation to Candidates' Quality $_{i t}$, the vector of controls $X_{i t}$, province fixed effect, electoral period fixed effects and a flexible functional form $f\left(P_{o p}\right.$ it $)$ relating the municipality population at the time of elections to Turnout ${ }_{i t}$. Equation [2] represents the first stage of the relationship between the quality of candidates running for a mayor position at election and the population size. In particular, by exploiting the exogenous variation in mayors' wage induced by the Italian Law, we use the salary paid to the mayor $\mathrm{Wage}_{i}$, as an instrument for the quality of politicians. The parameter $\gamma_{1}$ is the effect

\footnotetext{
${ }^{13}$ This result is consistent with findings emerging from De Paola and Scoppa (2011) and De Paola and Scoppa (2013).
} 
of the wage on the quality of candidates running for a mayor position. ${ }^{14}$ As we will discuss below, the $W a g e_{i}$ should affect the quality of candidates running for election, but should not affect through other channels electoral participation.

Equation [1] shows that electoral participation is related to municipal population, since in larger municipalities the quality of candidates running for election is typically higher. However, the relationship between electoral participation and population can be estimated using a smooth function. In our main specifications we use a first-order polynomial of population size. This functional form assumption fits the data well, and it does not appear to be overly restrictive as our results are robust to a series of alternative functional form assumptions (linear and quadratic spline at the population cutoffs and a second-order polynomial of the forcing variable). Under the assumption that the relationship between the outcome variable and population size is continuous in a neighborhood of the cutoffs, and that population size cannot be manipulated by the politicians (for example, the incumbent) any jump in the dependent variable in proximity of the cutoff points can be interpreted as evidence of a treatment effect. Therefore, the parameter $\beta_{1}$ measures the causal impact of candidates' quality on electoral participation.

Our investigation strategy strongly relies on Gagliarducci and Nannicini (2011), Ferraz and Finan (2009) and Kotakorpi and Poutvaara (2011), showing that the wage paid to elected officials has a positive impact on candidates' quality. In particular, Gagliarducci and Nannicini (2011), adopting the same data we use in this paper (but for a smaller sample and for a shorter time period), find that the wage affects politicians' performance mainly by increasing their quality. These results reassure us about the fact that the exogenous variation in wages should not affect turnout through other channels rather than the quality of candidates at the electoral race (our instrument is uncorrelated with unobservable determinants of the dependent variable). In the Appendix of the paper we present a number of checks on the validity of our identification strategy. In line with Gagliarducci and Nannicini (2011)' s findings, we show that the wage paid to the mayor does not affect either other candidates' characteristics, such as their age and gender, or some relevant features of the electoral race, such as the number of candidates and electoral closeness.

In this section, we report results from our preferred estimation method, Local Linear Regression (LLR henceforth) with optimal symmetric bandwidth (Porter, 2003). Our dependent variable is the number of voters on the number of electors (Turnout). In all specifications we include dummies for electoral periods and provincial dummies and we use a first-order polynomial for the forcing variable ${ }^{15}$ (i.e. population size). Further, standard errors are robust to heteroskedasticity and are allowed for clustering at the municipal level. As robustness checks, we also report results using the three population cutoffs as excluded instruments in a two-stage least squares setting (Van Der Klaauw, 2002; Ferraz and Finan, 2011) and results with different (spline) polynomial approximations over the entire sample (not reported and available upon request).

\footnotetext{
${ }^{14}$ In municipalities with populations above the cutoffs, legislators receive, on average, higher salaries compared to those legislators in municipalities below the cutoffs.

${ }^{15}$ Findings are similar also when we use a second-order polynomial for the population size.
} 
In Table 3 we show LLR estimates when considering a bandwidth of $-20 /+20$ percent around the 3 population cutoffs that uniquely identify a wage increase, i.e. municipalities in the ranges 800-1,200; 4,0006,000 and 40,000-60,000, respectively.

The First Stage (Panel B) confirms that the wage paid to the mayor strongly determines our measure of candidates' quality at the electoral race (Candidates' Education): candidates to a better paid office are characterized by higher levels of education. Moreover, we are reassured that our instrument is not weak, since the F-statistic for the test of whether the instrument coefficient is equal to zero is always well above the threshold value of 10 suggested by Staiger and Stock (1997).

Two Stage Least Squares (TSLS) estimates show that an increase in the candidates' quality leads to a higher turnout close to the three population thresholds.

In column (1), without controls for municipal and candidates' characteristics, we show that an increase of one year in the average educational attainment of candidates leads to an increase in turnout of about 1.8 percentage points. The effect is statistically significant at the one percent level.

In specification (2) including controls for municipal characteristics the effect slightly decreases in magnitude. Very similar results are obtained in column (3) including also controls for candidates' characteristics (a dummy for having at least a female among candidates, a dummy taking a value equal to 1 if the mayor in the previous legislature is among candidates and the average age of candidates). Our findings do not change also when we include controls for the degree of political competition (number of candidates running for a mayor position and the electoral margin) characterizing the electoral race (column 4).

Table 3. The Impact of Candidates’ Quality on Turnout: Local Linear Estimates ( $\pm 20 \%$ Bandwidth). Dependent Variable Turnout

(1) (2) (3) (4)

Panel A: Two-Stage Least Squares Estimates

\begin{tabular}{|c|c|c|c|c|}
\hline Candidates' Education & $\begin{array}{c}0.0184 * * * \\
(0.0051)\end{array}$ & $\begin{array}{c}0.0179 * * * \\
(0.0056)\end{array}$ & $\begin{array}{c}0.0180 * * * \\
(0.0056)\end{array}$ & $\begin{array}{c}0.0162 * * * \\
(0.0053)\end{array}$ \\
\hline Population Education & & $\begin{array}{c}0.0845 * * * \\
(0.0237)\end{array}$ & $\begin{array}{c}0.0846 * * * \\
(0.0239)\end{array}$ & $\begin{array}{c}0.0874 * * * \\
(0.0236)\end{array}$ \\
\hline Population Education^22 & & $\begin{array}{c}-0.0061^{* * * *} \\
(0.0016)\end{array}$ & $\begin{array}{c}-0.0062^{* * *} \\
(0.0016)\end{array}$ & $\begin{array}{c}-0.0063^{* * *} \\
(0.0016)\end{array}$ \\
\hline Employment & & $\begin{array}{l}0.0257^{*} \\
(0.0146)\end{array}$ & $\begin{array}{l}0.0243 * \\
(0.0147)\end{array}$ & $\begin{array}{l}0.0249 * \\
(0.0145)\end{array}$ \\
\hline Municipal Area & & $\begin{array}{l}-0.0604 \\
(0.0381)\end{array}$ & $\begin{array}{l}-0.0666^{*} \\
(0.0389)\end{array}$ & $\begin{array}{l}-0.0633^{*} \\
(0.0380)\end{array}$ \\
\hline Candidates’ Age & & & $\begin{array}{c}0.0008 * * \\
(0.0003)\end{array}$ & $\begin{array}{c}0.0008 * * \\
(0.0003)\end{array}$ \\
\hline Incumbent & & & $\begin{array}{l}-0.0028 \\
(0.0024)\end{array}$ & $\begin{array}{l}-0.0018 \\
(0.0025)\end{array}$ \\
\hline Female Candidate & & & $\begin{array}{c}-0.0063 * * \\
(0.0029)\end{array}$ & $\begin{array}{c}-0.0058^{* *} \\
(0.0028)\end{array}$ \\
\hline No. Candidates & & & & $\begin{array}{c}0.0021 \\
(0.0016)\end{array}$ \\
\hline Electoral Margin & & & & $\begin{array}{l}-0.0173 \\
(0.0117)\end{array}$ \\
\hline Population Polynomial & First & First & First & First \\
\hline Observations & 4,601 & 4,601 & 4,601 & 4,578 \\
\hline
\end{tabular}




\begin{tabular}{lcccc}
\hline \multicolumn{1}{c}{ Panel B: First Stage } & & \\
\hline Wage & $0.0007^{* * *}$ & $0.0007^{* * *}$ & $0.0007^{* * *}$ & $0.0007^{* * *}$ \\
& $(0.0001)$ & $(0.0001)$ & $(0.0001)$ & $(0.0001)$ \\
R-squared & 0.173 & 0.177 & 0.196 & 0.201 \\
First-Stage F- statistics & 97.41 & 77.26 & 79.21 & 85.00 \\
p-value & 0.0000 & 0.0000 & 0.0000 & 0.0000 \\
\hline \hline
\end{tabular}

Notes: The dependent variable is the electoral turnout (number of total ballots on the number of electors). In all the regressions we control for electoral period and province dummies (not reported). Standard errors (corrected for heteroskedasticity and clusterized at the municipality level) are reported in parentheses. The symbols $* * *, * *, *$ indicate that coefficients are statistically significant at the 1,5 , and 10 percent level.

To investigate whether it is sufficient to have at least a high-quality politician among candidates to induce individuals to take part into the democratic process and to cast their vote, we have also measured candidates' quality as the educational level acquired by the best educated candidate. In Table 4 we report the same specifications reported in Table 3 and measure candidates’ quality using Candidates' Max Education (control variables not reported to save space). Again, we find a positive and highly statistically significant effect. The impact is slightly smaller compared to that obtained when considering the average level of education of the whole pool of candidates. ${ }^{16}$

Table 4. The Impact of Candidates’ Quality on Turnout: Local Linear Estimates ( $\pm 20 \%$ Bandwidth). Dependent Variable Turnout

(1) (2)

Panel A: Two-Stage Least Squares Estimates

\begin{tabular}{|c|c|c|c|c|}
\hline Candidates’ Max Education & $\begin{array}{c}0.0162 * * * \\
(0.0045)\end{array}$ & $\begin{array}{c}0.0156 * * * \\
(0.0049)\end{array}$ & $\begin{array}{c}0.0158 * * * \\
(0.0049)\end{array}$ & $\begin{array}{c}0.0162 * * * \\
(0.0054)\end{array}$ \\
\hline Population Polynomial & First & First & First & First \\
\hline Observations & 4,601 & 4,601 & 4,601 & 4,578 \\
\hline
\end{tabular}

\begin{tabular}{lcccc}
\hline \multicolumn{4}{c}{ Panel B: First Stage } & \\
\hline Wage & $0.0008^{* * *}$ & $0.0008^{* * *}$ & $0.0007^{* * *}$ & $0.0007^{* * *}$ \\
& $(0.0001)$ & $(0.0001)$ & $(0.0001)$ & $(0.0001)$ \\
R-squared & 0.136 & 0.138 & 0.149 & 0.161 \\
First-Stage F- statistics & 113.85 & 91.39 & 91.58 & 75.51 \\
p-value & 0.0000 & 0.0000 & 0.0000 & 0.0000 \\
\hline \hline
\end{tabular}

Notes: The dependent variable is the electoral turnout (number of total ballots on the number of electors). In all the regressions we control for electoral period and province dummies (not reported). Standard errors (corrected for heteroskedasticity and clusterized at the municipality level) are reported in parentheses. The symbols $* * *,{ }^{* *},{ }^{*}$ indicate that coefficients are statistically significant at the 1,5 , and 10 percent level.

In Table 5 LLR results are reported when we consider a bandwidth of -10/+10 percent (900-1,100; 4,5005,500 and 45,000-55,000) around the population cutoffs. Again from the First Stage results, displayed in Panel $\mathrm{B}$, the wage earned by mayors strongly affects the decision of candidates to run for a mayor position. In all specifications we find results that are consistent with those reported in Table 3, however with this narrow bandwidth the magnitude of the effect doubles. For instance, in column (4), in which we add all our control variables, an exogenous increase of one year in the average educational attainment of candidates leads to an

\footnotetext{
${ }^{16}$ Very similar results are obtained also when we measure the candidates' quality as the type of job in which candidates are employed. In particular, we define High Skill as a dummy taking the value of 1 if candidates are "professionals" or "entrepreneurs" and 0 otherwise. Nearly $42 \%$ of candidates running for election are employed in high-skill jobs.
} 
increase in turnout of 3.2 percentage points. Similar results are found when we use, as a measure of candidates’ quality, the educational level acquired by the best educated candidate (not reported).

Table 5. The Impact of Candidates’ Quality on Turnout: Local Linear Estimates ( $\pm 10 \%$ Bandwidth). Dependent Variable Turnout

(1) (2) (3) (4)

Panel A: Two-Stage Least Squares Estimates

\begin{tabular}{|c|c|c|c|c|}
\hline Candidates' Education & $\begin{array}{c}0.0342 * * * \\
(0.0109)\end{array}$ & $\begin{array}{c}0.0349 * * * \\
(0.0120)\end{array}$ & $\begin{array}{c}0.0348 * * * \\
(0.0120)\end{array}$ & $\begin{array}{c}0.0320^{* * *} \\
(0.0110)\end{array}$ \\
\hline Population Education & & $\begin{array}{c}0.0396 \\
(0.0410)\end{array}$ & $\begin{array}{c}0.0337 \\
(0.0415)\end{array}$ & $\begin{array}{c}0.0379 \\
(0.0410)\end{array}$ \\
\hline Population Education^2 & & $\begin{array}{c}-0.0032 \\
(0.0028)\end{array}$ & $\begin{array}{c}-0.0029 \\
(0.0029)\end{array}$ & $\begin{array}{c}-0.0031 \\
(0.0028)\end{array}$ \\
\hline Employment & & $\begin{array}{c}0.0434 \\
(0.0273)\end{array}$ & $\begin{array}{c}0.0395 \\
(0.0270)\end{array}$ & $\begin{array}{c}0.0365 \\
(0.0259)\end{array}$ \\
\hline Municipal Area & & $\begin{array}{c}-0.0002^{* * *} \\
(0.0544)\end{array}$ & $\begin{array}{c}-0.0003 * * * \\
(0.0584)\end{array}$ & $\begin{array}{c}-0.0002^{* * *} \\
(0.0532)\end{array}$ \\
\hline Candidates’ Age & & & $\begin{array}{c}0.0016 * * \\
(0.0007)\end{array}$ & $\begin{array}{c}0.0016^{* *} \\
(0.0007)\end{array}$ \\
\hline Incumbent & & & $\begin{array}{c}-0.0004 \\
(0.0042)\end{array}$ & $\begin{array}{c}-0.0006 \\
(0.0042)\end{array}$ \\
\hline Female Candidate & & & $\begin{array}{c}-0.0078 \\
(0.0055)\end{array}$ & $\begin{array}{c}-0.0064 \\
(0.0050)\end{array}$ \\
\hline No. Candidates & & & & $\begin{array}{c}0.0031 \\
(0.0026)\end{array}$ \\
\hline Electoral Margin & & & & $\begin{array}{c}0.0078 \\
(0.0242)\end{array}$ \\
\hline Population Polynomial & First & First & First & First \\
\hline Observations & 2,294 & 2,294 & 2,294 & 2,282 \\
\hline
\end{tabular}

\begin{tabular}{|c|c|c|c|c|}
\hline \multicolumn{5}{|c|}{ Panel B: First Stage } \\
\hline Wage & $\begin{array}{c}0.0006 * * * \\
(0.0001)\end{array}$ & $\begin{array}{c}0.0005^{* * *} \\
(0.0001)\end{array}$ & $\begin{array}{c}0.0005^{* * *} \\
(0.0001)\end{array}$ & $\begin{array}{c}0.0006 * * * \\
(0.0001)\end{array}$ \\
\hline R-squared & 0.183 & 0.186 & 0.201 & 0.214 \\
\hline First-Stage F- statistics & 31.92 & 26.11 & 26.62 & 29.16 \\
\hline p-value & 0.0000 & 0.0000 & 0.0000 & 0.0000 \\
\hline
\end{tabular}

Notes: The dependent variable is the electoral turnout (number of total ballots on the number of electors). In all the regressions we control for electoral period and province dummies (not reported). Standard errors (corrected for heteroskedasticity and clusterized at the municipality level) are reported in parentheses. The symbols $* * *, * *$, indicate that coefficients are statistically significant, respectively, at the 1,5 , and 10 percent level.

In Table 6 we investigate whether male and female electors react differently to an exogenous increase in candidates’ quality. LLR estimates reported in Table 6 (specification with the full set of controls) show that both male and female voters react positively to an increase in politicians' quality. The reaction of male and female electors is similar. For example, in column (1) and (2), with a bandwidth of $-20 /+20$ percent, males increased their turnout by about 2.2 percentage points, while the increase is 2 percentage points for females. 
Table 6. The Impact of Candidates' Quality on Male and Female Turnout: Local Linear Estimates

(1)

Male Turnout

\begin{tabular}{|c|c|c|c|c|}
\hline \multicolumn{5}{|c|}{ Panel A: Two-Stage Least Squares Estimates } \\
\hline Candidates’ Education & $\begin{array}{c}0.0218 * * * \\
(0.0060)\end{array}$ & $\begin{array}{c}0.0198 * * * \\
(0.0056)\end{array}$ & $\begin{array}{c}0.0329 * * * \\
(0.0101)\end{array}$ & $\begin{array}{c}0.0304^{* * *} \\
(0.0095)\end{array}$ \\
\hline Population Polynomial & First & First & First & First \\
\hline Controls & All & All & All & All \\
\hline Bandwidth & $\pm 20 \%$ & $\pm 20 \%$ & $\pm 10 \%$ & $\pm 10 \%$ \\
\hline Observations & 2,598 & 2,579 & 1,286 & 1,279 \\
\hline \multicolumn{5}{|c|}{ Panel B: First Stage } \\
\hline Wage & $\begin{array}{c}0.0007 * * * \\
(0.0001)\end{array}$ & $\begin{array}{c}0.0007^{* * *} \\
(0.0001)\end{array}$ & $\begin{array}{c}0.0007 * * * \\
(0.0001)\end{array}$ & $\begin{array}{c}0.0007 * * * \\
(0.0001)\end{array}$ \\
\hline R-squared & 0.203 & 0.204 & 0.209 & 0.209 \\
\hline First-Stage F- statistics & 51.55 & 50.98 & 24.21 & 23.33 \\
\hline p-value & 0.0000 & 0.0000 & 0.0000 & 0.0000 \\
\hline
\end{tabular}

Notes: The dependent variable is measured by male turnout (number of male voters on the number of male electors) and female turnout (number of female voters on the number of female electors) respectively. In all the regressions we control for electoral period and province dummies (not reported), municipal and candidates' characteristics. Standard errors (corrected for heteroskedasticity and clusterized at the municipality level) are reported in parentheses. The symbols $* * *, * *, *$ indicate that coefficients are statistically significant, respectively, at the 1,5 , and 10 percent level.

\section{Robustness checks}

In this section we check the robustness of our results. Firstly, we use the three population cutoffs that uniquely identify an increase in mayor's wage as excluded instruments in a two-stage least squares setting (Van Der Klaauw, 2002; Ferraz and Finan, 2011) by choosing a bandwidth of 20 and 10 percent above and below the population thresholds respectively, and by controlling for a first-order polynomial of our forcing variable, i.e. population size.

TSLS results are displayed in Table 7. In the first two columns the bandwidth is $-20 /+20$ percent above and below the three population thresholds. Furthermore, in column (1) we control for provincial and electoral period dummies only, whereas in column (2) we add the full set of our controls. The effect of our variable of interest on the electoral participation is still positive and stable across the two specifications. In addition, an increase of one year in the average educational attainment of candidates leads to an increase in turnout of 1.1 percentage points (see column 2).

First Stage Results are shown in Figure 1 (Panel a, b and c). In particular, we plot, respectively, the average quality of candidates at the electoral race against the number of inhabitants, close to the three different thresholds defining the mayor's wage (1,000; 5,000 and 50,000), with a bandwidth of -20/+20 percent above and below the cutoffs. 


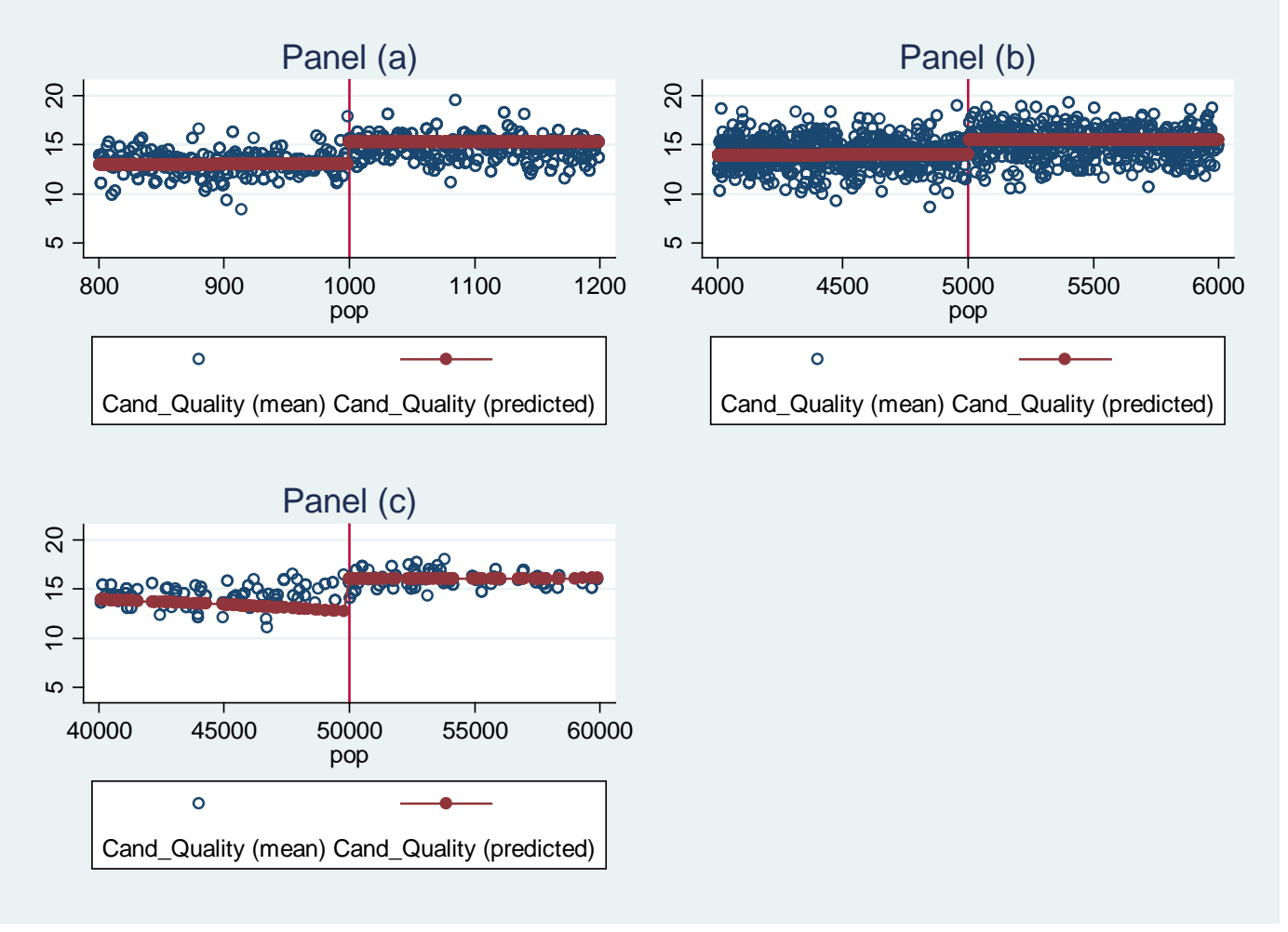

Figure 1: First Stage Results - Effect of Mayor’s Wage on Average Candidates’ Quality

The circles are the mean of years of education of candidates at electoral races for a given number of inhabitants in the municipality, while the connected points are the predicted values from the first stage equation. As it is possible to see in the left side of the graph in Figure 1, Panel (a), in municipalities with a population around the 1,000 threshold, candidates at electoral races in municipalities below the cutoff have on average 14 years of education, while those above the cutoff have acquired about 15 years of education. Similar results are found in Panel (b) in which we focus on municipalities around the 5,000 threshold. A sharp increase in the average educational attainment of candidates at the cutoff is observed also for municipalities around the 50,000 threshold in Panel (c).

The F-stat from the First Stage in Table 7, confirms that the excluded instruments are not weak since its value is always larger than 10 and statistically significant at 1 percent level. Moreover, our model does not seem to be over-identified: in fact, by implementing the Sargan test, we never reject (in all the specifications), the joint null hypothesis that the instruments are valid instruments, i.e., uncorrelated with the error term, and that the excluded instruments are correctly excluded from the estimated equation.

Similar results are found when we use a small discontinuity sample with a bandwidth of $-10 /+10$ percent in the neighborhood of the three thresholds: the effect of candidates' quality on voter turnout is positive and statistically significant at 1 percent level.

Our results are also robust to alternative functional forms of the population size (a linear spline and a quadratic spline of the forcing variable over the entire sample), by using again the three population thresholds as excluded instruments in a TSLS setting (results not reported and available upon request). 
Table 7. Local Linear Estimates with Population Thresholds as Excluded Instruments

(1)

(2)

(3)

(4)

Panel A: Two-Stage Least Squares Estimates

\begin{tabular}{lcccc} 
VARIABLES & Turnout & Turnout & Turnout & Turnout \\
\hline Candidates' Education & $0.0134^{* *}$ & $0.0103^{*}$ & $0.0286^{* * *}$ & $0.0256^{* * *}$ \\
& $(0.0056)$ & $(0.0061)$ & $(0.0101)$ & $(0.0100)$ \\
Population Polynomial & First & First & First & First \\
Controls & No & All & No & All \\
Bandwidth & $\pm 20 \%$ & $\pm 20 \%$ & $\pm 10 \%$ & $\pm 10 \%$ \\
Observations & & & 2,294 & 2,282 \\
\hline \hline
\end{tabular}

\begin{tabular}{lcccc}
\hline \hline & Panel B: First Stage & & & \\
\hline Threshold 1,000 & $0.6247^{* * *}$ & $0.5399 * * *$ & $0.5324^{* * *}$ & $0.4708^{* * *}$ \\
& $(0.1077)$ & $(0.1066)$ & $(0.1527)$ & $(0.1509)$ \\
Threshold 5,000 & $0.3320^{* * *}$ & $0.3132^{* * *}$ & $0.3709^{* * *}$ & $0.3858^{* * *}$ \\
& $(0.0863)$ & $(0.0857)$ & $(0.1177)$ & $(0.1173)$ \\
Threshold 50,000 & $0.5747^{* *}$ & $0.6016^{*}$ & 0.2270 & 0.3221 \\
& $(0.2976)$ & $(0.2941)$ & $(0.3798)$ & $(0.3765)$ \\
R-squared & 0.166 & 0.204 & 0.181 & 0.213 \\
First-Stage F- statistics & 14.89 & 14.86 & 10.44 & 10.10 \\
p-value & 0.0000 & 0.0000 & 0.0000 & 0.0000 \\
Over-identification statistics & 4.572 & 4.517 & 0.741 & 0.614 \\
p-value & 0.11 & 0.114 & 0.690 & 0.736 \\
\hline \hline
\end{tabular}

Notes: The dependent variable is the electoral turnout (number of total ballots on the number of electors). In all the regressions we control for electoral period and province dummies (not reported). Standard errors (corrected for heteroskedasticity and clusterized at the municipality level) are reported in parentheses. The symbols $* * *, * *, *$ indicate that coefficients are statistically significant, respectively, at the 1,5 , and 10 percent level.

Finally, in Table 8, we implement a placebo test by estimating the effect of candidates' quality on electoral participation by using three fake thresholds $(4,000 ; 7,000$ and 70,000) as excluded instruments in a TSLS setting, where no policy is expected to change (including the mayor's wage) in their neighborhoods. In the first two columns we choose a bandwidth of -20/+20 percent above and below the cutoffs, whereas in the last two columns the bandwidth is $-10 /+10$ percent close to the population thresholds. Furthermore, in the oddnumbered columns we control for population size, while in the even-numbered columns we adopt a quadratic polynomial of the forcing variable.

All in all the effect of candidates' quality, as measured by the average years of schooling of candidates running for a mayor position, is never statistically different from zero close to the fake thresholds, since the three excluded instruments are very weak, as highlighted by the F-stat from the First Stage in Table 8.

Results are very similar also when we use other fake thresholds as instruments for candidates' quality (data available upon request). 
Table 8. Placebo Test at Fake Thresholds

(1)

(2)

(3)

(4)

Panel A: Two-Stage Least Squares Estimates

\begin{tabular}{lcccc} 
VARIABLES & Turnout & Turnout & Turnout & Turnout \\
\hline Candidates' Education & -0.0098 & -0.0083 & -0.0263 & -0.0289 \\
& $(0.0153)$ & $(0.0198)$ & $(0.0299)$ & $(0.0343)$ \\
Population Polynomial & First & Second & First & Second \\
Controls & All & All & All & All \\
Bandwidth & $\pm 20 \%$ & $\pm 20 \%$ & $\pm 10 \%$ & $\pm 10 \%$ \\
Observations & & & 2,624 & 2,624 \\
\hline \hline
\end{tabular}

\begin{tabular}{lcccc}
\hline \hline \multicolumn{1}{c}{ Panel B: First Stage } & & & \\
\hline Threshold 4,000 & $0.1924 * * *$ & $0.1459 *$ & 0.1526 & 0.1471 \\
& $(0.0696)$ & $(0.0838)$ & $(0.1033)$ & $(0.1243)$ \\
Threshold 7,000 & -0.0062 & -0.0648 & -0.0719 & -0.0787 \\
& $(0.0801)$ & $(0.0994)$ & $(0.1119)$ & $(0.1399)$ \\
Threshold 70,000 & -0.1351 & 0.2816 & -0.3224 & -0.2988 \\
& $(0.3870)$ & $(0.5699)$ & $(0.5728)$ & $(0.6438)$ \\
R-squared & 0.202 & 0.198 & 0.188 & 0.189 \\
First-Stage F- statistics & 1.86 & 1.17 & 0.66 & 0.56 \\
p-value & 0.1337 & 0.3204 & 0.5769 & 0.6388 \\
Over-identification statistics & 3.181 & 3.992 & 0.310 & 0.607 \\
p-value & 0.204 & 0.136 & 0.856 & 0.738 \\
\hline \hline Notes: The dependent variable is the electoral turnout (number of total ballots on the number of electors). In all the regressions we control for \\
electoral period and province dummies (not reported). Standard errors (corrected for heteroskedasticity and clusterized at the municipality level) are \\
reported in parentheses. The symbols ***, $* *$, indicate that coefficients are statistically significant, respectively, at the 1, 5, and 10 percent level.
\end{tabular}

\section{Concluding remarks}

The crucial role played by good politicians in enhancing adequate policies and in improving economic performance has been largely investigated in the literature (Besley et al., 2007; Jones and Olken, 2005; Besley, 2007). Furthermore, some empirical studies have considered whether politicians' quality matters to shape voters behavior. These works have mainly focused on US elections, showing that the degree of competition characterizing the elections is influenced by the quality of the incumbent and that high-quality candidates have more electoral success (see Jacobson and Kernell, 1983; Lublin, 1994; Carson et al., 2001; Stone and Maisel, 2003; Stone et al., 2010). However, no studies have been devoted at investigating the effect of politicians' quality on civic participation, although political participation is at the basis of a well functioning political system.

In this paper using a rich data set on Italian municipal elections we have investigated the effects produced by candidates' quality on electoral turnout. We have firstly estimated a municipal fixed effects model. We find that increasing candidates' average education by 1 year increases electoral turnout by about 0.9 percentage points. This result holds true also when we control for other candidates' characteristics, such as age and gender, and for the degree of political competition characterizing the electoral race.

To handle endogeneity problems arising from the fact that candidates' quality may be correlated to time variant unobservable variables that affect both the decision of high-quality candidates to compete at the electoral race and the electoral participation, we have used a Fuzzy Regression Discontinuity Design relying 
on the fact that in Italy the wage of the mayor increases at different population thresholds. In particular, we have restricted the analysis to the thresholds that uniquely identify an increase in the mayor's remuneration. The mayor's wage in the First Stage regression seems to be strongly correlated to the average educational attainment of candidates and should not directly affect the electoral participation.

TSLS estimation results confirm FE estimates, although they are larger in terms of magnitude, highlighting the fact that FE estimates are downward biased due to either a negative correlation between the decision of highly educated individuals to enter politics and individuals' decision to cast their vote or to measurement errors. We find that an increase of 1 year in the average education of candidates increases turnout by about 2 percentage points.

Similar results are found when we choose a smaller bandwidth close to the neighborhood of our thresholds or when we alternatively control for a second-order polynomial of the forcing variable, i.e. population size, and for a linear and quadratic spline at the population cutoffs. In addition, the effect of candidates' quality on the electoral participation remains substantially unchanged whether we use the three population cutoffs that uniquely identify an increase in mayor's wage as excluded instruments in a two-stage least squares setting (Van Der Klaauw, 2002; Ferraz and Finan, 2011) by choosing different bandwidths above and below the population thresholds.

All in all our results suggest that education, considered as a proxy for politicians' quality, in addition to the positive effect produced on growth, performance of legislators and efficiency of the public administration, may also affect electors' behavior, inducing them to cast their vote because they may infer a higher political competence. 


\section{References}

Accetturo, A., 2013. Political selection in the skilled cities. Bank of Italy Working Paper, Structural Economic Analysis Department, Bank of Italy.

Angrist, JD., Pischke, JS., 2009. Mostly harmless econometrics: an empiricist's companion. Princeton University Press.

Baltrunaite, A., Bello, P., Casarico, A., Profeta, P., 2012. Gender quotas and the quality of politicians. Working Paper No. 3734, CESifo, Munich.

Barber, BR., 1984. Strong democracy: participatory politics for a new age. Berkeley: University of California Press.

Barone, G., De Blasio, G., 2013. Electoral rules and voter turnout. International Review of Law and Economics 36, 25-35.

Besley, T., 2007. Principled agents? The political economy of good government. Oxford University Press, USA.

Besley, T., Coate, S., 1997. An economic model of representative democracy. The Quarterly Journal of Economics 112, 85-114.

Besley, T., Persson,T., Sturm, D.M., 2007. Political competition, policy and growth: theory and evidence from the US. The Review of Economic Studies 77, 1329-1352.

Besley, T., Montalvo, J.G., Reynal-Querol, M., 2011. Do educated leaders matter? The Economic Journal 121, 205-227.

Borgonovi, F., d'Hombres, B., Hoskins, B., 2010. Voter turnout, information acquisition and education: evidence from 15 European countries. The B.E. Journal of Economic Analysis and Policy 10, Article 90.

Brollo, F., Nannicini, T., Perotti, R., Tabellini, G., 2012. The political resource curse. NBER Working Paper.

Carson, J.L., Jenkins, J.A., Rohde, D.W., Souva, M.A., 2001. The impact of national tides and district-level effects on electoral outcomes: the congressional elections of 1862-63. American Journal of Political Science 45, 887-98.

Caselli, F., Morelli, M., 2004. Bad politicians. Journal of Public Economics 88, 759-782.

De Paola, M., Scoppa, V., 2011. Political competition and politician quality: evidence from Italian municipalities. Public Choice 148, 547-559.

De Paola, M., Scoppa, V., 2013. The impact of closeness on electoral participation exploiting the Italian double ballot system, Public Choice

Dee, T.S., 2004. Are there civic returns to education? Journal of Public Economics 88, 1697-1720.

Ferraz, C., Finan, F., 2011. Motivating politicians: the impacts of monetary incentives on quality and performance. NBER Working Paper.

Gagliarducci, S., Nannicini, T., 2011. Do better paid politicians perform better? Disentangling incentives from selection. Journal of the European Economic Association 11, 369-398.

Galasso, V., Nannicini, T., 2011. Competing on good politicians. American Political Science Review 105, 7999.

Glaeser, EL., Ponzetto, GAM, Shleifer, A. 2007. Why does democracy need education? Journal of economic growth 17, 77-99.

Jacobson, G.C., Kernell, S., 1983. Strategy and choice in congressional elections. Yale University Press.

Jones, B.F., Olken, B.A., 2005. Do leaders matter? National leadership and growth since World War II. The Quarterly Journal of Economics 120, 835-864.

Kotakorpi, K. and Poutvaara P. (2011), Pay for politicians and candidate selection: An empirical analysis, Journal of Public Economics, 95 (7-8), 877-885.

Lee, DS., Lemieux, T., 2009. Regression discontinuity designs in economics. NBER Working Paper.

Lublin, D., 1994. Quality, not quantity: strategic politicians in US senate elections, 1952-1990. Journal of Politics 56, 228-241.

Matsusaka, JG., Palda, F., 1999. Voter turnout: how much can we explain? Public Choice 98, 431-446. 
Messner, M., Polborn, M.K., 2004. Paying politicians. Journal of Public Economics 88, 2423-2445.

Milligan, K., Moretti, E., Oreopoulos, P., 2004. Does education improve citizenship? Evidence from the United States and the United Kingdom. Journal of Public Economics 88, 1667-1695.

Osborne, M.J., Slivinski, A., 1996. A model of political competition with citizen-candidates. The Quarterly Journal of Economics 111, 65-96.

Pateman, C., 1970. Participation and democratic theory. Cambridge University Press.

Porter, J., 2003. Estimation in the regression discontinuity model. Working Paper, Department of Economics, Cambridge.

Poutvaara, P., Takalo, T., 2007. Candidate quality. International Tax and Public Finance 14, 7-27.

Scholzman, K.L., 2002. Citizen participation in America: what do we know? Why do we care? In: Ira Katznelson, Helen V. Milner (ed.), Political Science: The State of the Discipline.

Siedler, T., 2007. Schooling and citizenship: evidence from compulsory schooling reforms. IZA Discussion Paper No.2573, IZA, Bonn.

Staiger, D., Stock, J., 1997. Instrumental variables regression with weak instruments. Econometrica 65, 557586.

Stone, W.J., Maisel, L.S., 2003. The not-so simple calculus of winning: potential U.S. House candidates' nomination and general election chances. Journal of Politics 65, 951-77.

Stone, W.J., Fulton, S.A., Maestas, C.D., Maisel, L.S., 2010. Incumbency reconsidered: prospects, strategic retirement, and incumbent quality in U.S. House elections. Journal of Politics 72, 178-90.

Van Der Klaauw, W., 2002. Estimating the effect of financial aid offers on college enrollment: a regression discontinuity approach. International Economic Review 43, 1249-1287. 


\section{Appendix}

\section{Smoothness condition and validity of the Fuzzy RDD}

The general concern with our identification strategy is the possibility that some other determinants of electoral participation also exhibits a stepwise function or are discontinuous at the various cutoff points. The main assumption underlying our approach is that unobserved characteristics do not change discontinuously around population thresholds, i.e. the pre-determined characteristics of municipalities just above and below the thresholds are the same. Since information about unobserved characteristics is not available, the focus is on observed characteristics. Similar checks are performed in a number of existing papers exploiting legislative thresholds in Italian municipalities (see for example Gagliarducci and Nanninicini, 2013; Barone and De Blasio, 2013).

Discontinuity in the Pre-determined Characteristics (1,000 Threshold)-Panel A
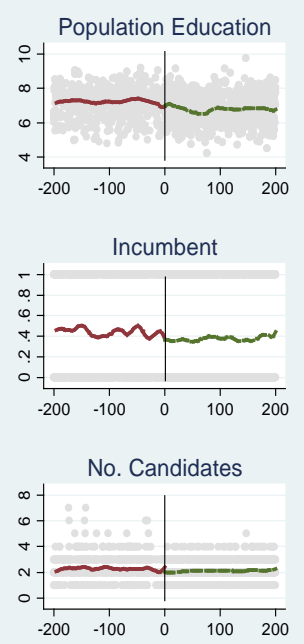
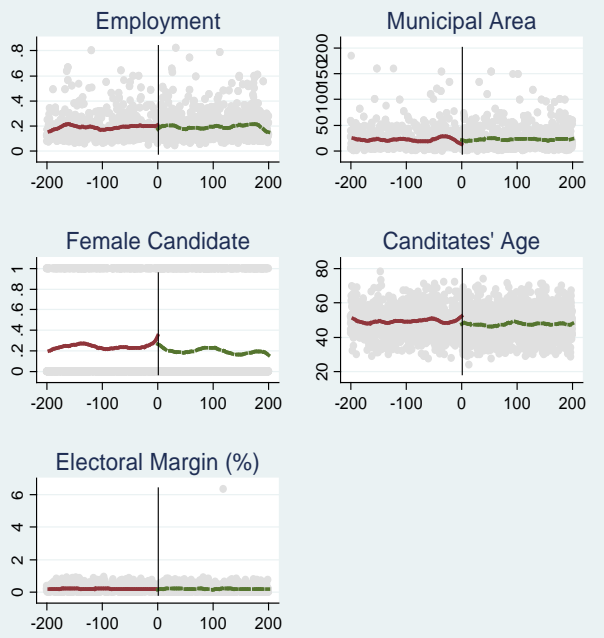

Discontinuity in the Pre-Determined Characteristics (5,000 Threshold)- Panel B
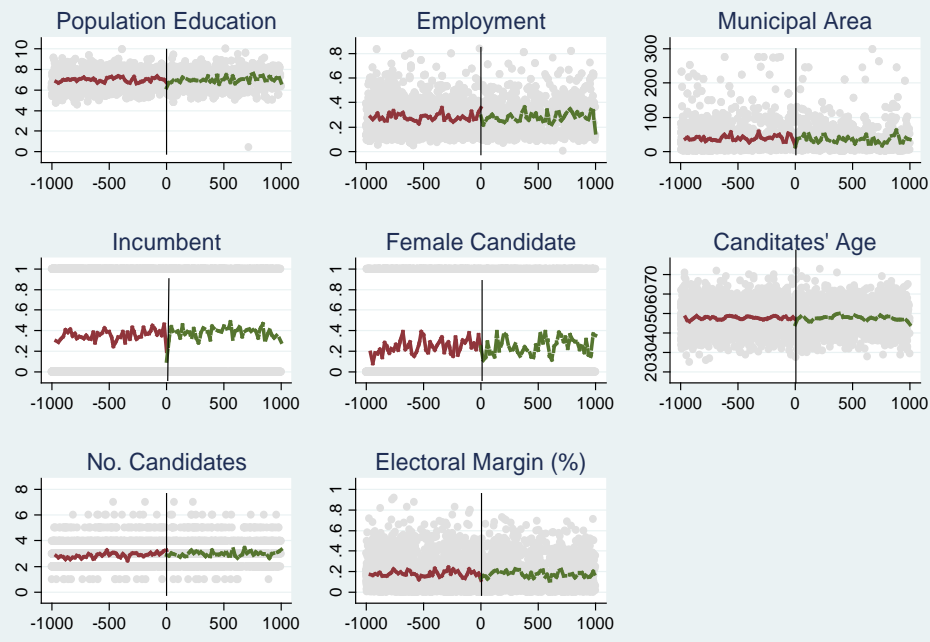

Discontinuity in the Pre-determined Characteristics (50,000 Threshold)-Panel C
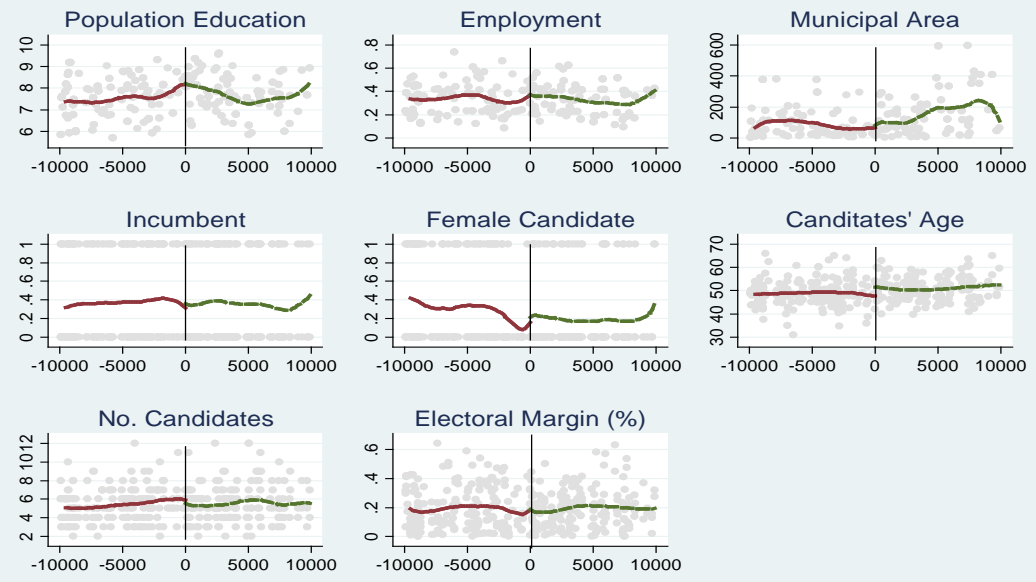

Figure A1: Discontinuity in the Pre-Determined Characteristics

Following the existing literature, in Figure A1 we present the pre-determined characteristics plotted against population size. Each figure depicts population cell means of the pre-determined characteristics in the 
neighborhood of the three population thresholds that uniquely identify the wage increase, along with the fitted values of a locally weighted regression calculated within each segment. In general, the figures show only small differences at each threshold points.

Moreover, as a further specification test, we present in Table A1, a difference-in-mean test for the predetermined characteristics mentioned above. In particular, we test whether there is a statistically significant difference in terms of municipal, candidates and electoral races' characteristics among municipalities just above and below the population thresholds (1,000; 5,000 and 50,000), by considering the discontinuity samples with a bandwidth of 20 and 10 percent above and below the thresholds respectively. In the absence of manipulation, observable and unobservable variables should not differ significantly around the population thresholds.

As shown in Table A1, some of the pre-determined characteristics are statistically different from zero for the different groups of municipalities when we consider a discontinuity sample with a bandwidth of 20 percent, but the significance level of the difference in mean tends to disappear when municipalities in a smaller range (bandwidth of 10 percent) around the thresholds are compared. This reassures us about the random assignment around the threshold points (Imbens and Lemieux, 2008). As not all the pre-determined characteristics are balanced, we control for these variables in the regressions to avoid any bias due to the lack of balance.

Table A1. Difference-in-mean Test for the Pre-determined Characteristics

\begin{tabular}{|l|l|l|l|l|l|l|}
\hline \hline \multirow{2}{*}{ Variables } & \multicolumn{3}{c|}{ Bandwidth $\pm \mathbf{2 0}$ \% } & \multicolumn{3}{c|}{ Bandwidth $\pm \mathbf{1 0} \%$} \\
\cline { 2 - 7 } & \multicolumn{1}{|c|}{$\mathbf{1 , 0 0 0}$} & $\mathbf{5 , 0 0 0}$ & $\mathbf{5 0 , 0 0 0}$ & $\mathbf{1 , 0 0 0}$ & $\mathbf{5 , 0 0 0}$ & \multicolumn{1}{|c|}{$\mathbf{5 0 , 0 0 0}$} \\
\hline Population Education & $0.0357^{* * *}$ & 0.0301 & $0.0974^{* *}$ & $0.0506^{* *}$ & 0.0412 & $0.1259^{*}$ \\
\hline Employment & 0.5582 & 0.0048 & 0.0142 & 0.0067 & 0.0066 & 0.0190 \\
\hline Municipal Area & 0.8939 & 1.4188 & 12.6620 & 1.2567 & 1.9905 & 13.2599 \\
\hline Incumbent & $0.0211^{* * *}$ & $0.0170^{*}$ & 0.0520 & $0.0296^{* *}$ & 0.0239 & 0.0714 \\
\hline Female Candidate & $0.0177^{* *}$ & 0.0151 & $0.0469^{* * *}$ & 0.0252 & 0.0213 & 0.0622 \\
\hline Candidates' Age & $0.3521^{* * *}$ & 0.2494 & $0.5762^{* * *}$ & 0.4986 & 0.3511 & 0.7686 \\
\hline Electoral Margin (\%) & 0.0102 & 0.0054 & 0.0153 & 0.0115 & 0.0076 & 0.0198 \\
\hline No. Candidates & $0.0301^{* * *}$ & $0.0319^{* * *}$ & 0.2066 & $0.0401^{* *}$ & 0.0461 & 0.2716 \\
\hline \hline
\end{tabular}

As a last robustness check, in Table A2 we test whether the mayor's wage is predictive of a larger set of municipal and mayor' characteristics, by choosing a bandwidth of 20 and 10 percent above and below the thresholds respectively, and by controlling for a second-order polynomial of the population size.

Overall, the table confirms that there are no significant differences at the cutoff points for all the characteristics of municipalities, electoral race and candidates running for a mayor position, with a bandwidth of 10 percent in the neighborhood of the cutoff points. This suggests that the wage is unlikely to affect turnout through other channels rather than the change it induces in the quality of candidates running for election. 
Table A2. Robustness Test: Smoothness

\begin{tabular}{|l|c|c|}
\hline \hline \multicolumn{1}{|c|}{ Variables } & \multicolumn{2}{c|}{ Coefficient on Mayor's Wage } \\
\cline { 2 - 3 } & $\begin{array}{c}\text { Bandwidth } \pm \mathbf{2 0} \% \\
\mathbf{( 1 )}\end{array}$ & $\begin{array}{c}\text { Bandwidth } \pm \mathbf{1 0} \text { \% } \\
(\mathbf{2})\end{array}$ \\
\hline Population Education & $0.0001^{*}$ & 0.00004 \\
& $(0.0000)$ & $0.0001)$ \\
\hline Employment & $0.0001^{* * *}$ & $(0.0000)$ \\
& $(0.0000)$ & 0.0149 \\
& $0.0149^{* *}$ & $(0.0083)$ \\
\hline Incumbent & $(0.0074)$ & 0.0001 \\
& -0.0001 & $(0.0000)$ \\
\hline Female Candidate & $(0.0000)$ & -0.0001 \\
& -0.0001 & $(0.0000)$ \\
\hline Candidates' Age & $(0.0000)$ & 0.0002 \\
& 0.0002 & $(0.0005)$ \\
\hline Electoral Margin (\%) & $(0.0003)$ & -0.0001 \\
& $-0.0001 * * *$ & $(0.0000)$ \\
\hline No. Candidates & $(0.0000)$ & -0.0001 \\
& 0.0001 & $(0.0001)$ \\
\hline \hline
\end{tabular}

Notes: The dependent variable is specified in each row. The regression regresses the dependent variable on the mayor's wage. In each regression we control for, electoral period dummies and a quadratic polynomial of the population size. Robust standard errors are in brackets, clustered at municipal level. The symbols $* * *, * * *$ indicate that coefficients are statistically significant, respectively, at the 1,5 , and 10 percent level. 